\title{
The ACTH test in the diagnosis of hirsutism
}

\author{
Department of Gynecology - Escola Paulista de Medicina - Federal University of São Paulo - São Paulo Brazil
}

The ACTH test has been used to confirm the diagnosis of adrenal insufficiency and the classic and the non-classic adrenal hyperplasia due to the 3-HSD, $21 \mathrm{OH}$ e $110 \mathrm{O}$ deficiencies. This article reviews the historical aspects of the use of ACTH in the diagnosis of hirsutism and points out its mains indications. In spite of new biological molecular advances in the diagnosis of adrenal enzymatic deficiencies, the use of the ACTH test can help the physician to predict both genothipus and fenothipus in populations with hyperandrogenic manifestations due to non-classical or late-onset congenital adrenal hyperplasia.

UNITERMS: ACTH, diagnosis, hirsutism, adrenal hyperplasia

\section{INTRODUCTION}

\section{Historical aspects}

$\mathrm{S}$ ince the introduction of the test involving infusion of pituitary adrenocorticotropin hormone (ACTH) in $1948,{ }^{\prime}$ clinicians and gynecologists in general have been using the method to evaluate adrenal function in patients suspected of having adrenal insufficiency or congenital adrenal hyperplasia.

As far as the gynecological aspects are concerned, clinicians must be alert to the interpretation of the test; recent publications point out that patients with congenital adrenal hyperplasia in its late-onset or non-classical form may present a clinical picture consisting of irregular menses, hirsutism and other hyperandrogenic manifestations.

ACTH is a physiological agent that stimulates the biosynthesis of the adrenal cortex layers and is directly

\section{Address for correspondence: \\ Marco Fábio Prata Lima. \\ Rua São Sebastião, 67 - Centro \\ Uberaba/MG - Brazil - CEP 38010-430,}

stimulated by the corticotropin releasing factor (CRF) of hypothalamic origin. Thus, the adrenal cortex is evaluated clinically on the basis of its response to $\mathrm{ACTH}$ administration.

At first the test was used only for patients with adrenal insufficiency ${ }^{2}$ and was considered to be costly and highly complex. With the advent of cosyntropin, a synthetic ACTH derivative that reduced allergic phenomena, the test started to be used to diagnose late-onset synthesis deficiencies, i.e., the non-classical cases suspected of congenital adrenal hyperplasia.

Most reports unanimously state that after ACTH stimulation, there is an important increase of almost all androgen precursors; for this reason, the test may identify patients with late-onset 21-OH (21-hydroxilasis) and 11$\mathrm{OH}$ deficiency (11-hydroxilasis), as well as 3-HSD (3hydroxysteroid dehydrogenasis) deficiency. ${ }^{3}$

Thus, the test started to be employed more frequently in the late 1960s, with different doses and routes being used. ${ }^{4.5}$ Today, the test is performed by intravenous infusion of $0.25 \mathrm{mg} \mathrm{ACTH} \mathrm{H}^{1.2}$ followed by blood collection 30 to 60 minutes later. The test can determine with precision the glandular adrenal reserve for each hormone separately. By studying the relationships between the hormones and their respective precursors, it is possible to determine diagnostic patterns for the deficiency of enzymes possibly 
involved in the etiology of hyperandrogenism, especially 3-hydroxysteroid dehydrogenase (3-HSD, 21-hydroxylase $(21-\mathrm{OH})$ and 11 -hydroxylase $(11-\mathrm{OH}){ }^{6}$

Despite the established use of the test, the literature is not unanimous about its indication. CHETKOWISKI et al., after evaluating patients with late-onset $21-\mathrm{OH}$ deficiency, concluded that the ACTH test does not precisely identify these patients, in addition to being excessively costly.

\section{DIAGNOSTIC OF THE ENZIMATIC DEFICIENCIES}

In the detection of late-onset 21-OH deficiency, measuring $17-\mathrm{OH}$-progesterone after stimulus provides an important source of additional information. ${ }^{8}$ The diagnosis of this deficiency is based on the evaluation of plasma 17 $\mathrm{OH}$-progesterone levels; however, the literature has reported different interpretations of the test.

AZZIZ \& ZACUR consider women to be carriers when their 17-OH-progesterone levels exceed $1200 \mathrm{ng} / \mathrm{dl}$ after intravenous ACTH infusion. ${ }^{8}$ In contrast, DEWAILLY et al. suggested that patients with $17 \mathrm{OH}$ progesterone levels exceeding $500 \mathrm{ng} / \mathrm{dl}$ which are reduced by dexamethasone should not be submitted to the ACTH stimulation test as they would be considered to have nonclassical 21-OH deficiency. When these values are between 200 and $500 \mathrm{ng} / \mathrm{dl}$, the patient would be considered borderline and should be submitted to the test. Those with levels of less than $200 \mathrm{ng} / \mathrm{dl}$ would not be considered to have late-onset $21-\mathrm{OH}$ deficiency.

In the Endocrine Gynecology Sector of the Department of Gynecology, Escola Paulista de Medicina, Federal University of São Paulo, we use the NEW nomogram to evaluate these patients. With respect to 11$\mathrm{OH}$ deficiency, which is much more rare, measurement of compound S basely and after ACTH is also helpful for diagnosis. There are no clear criteria to identify these patients.

To evaluate 3-HSD activity, the diagnostic criteria most frequently employed were those proposed by PANG et al., i.e.: 1. post-stimulus 17-OH-pregnenolone levels two standard deviations above the levels detected in normal women (5 $17 \mathrm{OH}-\mathrm{P}>1639 \mathrm{ng} / \mathrm{dl}$ or $49.2 \mathrm{nmol} / 1)$; 2 . poststimulus DHEA levels two standard deviations above the levels observed in normal women (DHEA $>1818 \mathrm{ng} / \mathrm{dl}$ or $63.1 \mathrm{nmol} / 1$ ); $3.17 \mathrm{OH}$-pregnenolone/17OH-progesterone ratio two standard deviations above the values detected in normal women $(17 \mathrm{OH}$-progesterone $>6.4)$; and $4.17 \mathrm{OH}$ pregnenolone/cortisol ratio two standard deviations above normal values ( $17 \mathrm{OH}$-pregnenolone/cortisol $>52) .{ }^{10}$

Although these diagnostic criteria are widely accepted, they are not unanimously endorsed. GIBSON et al. used pregnenolone measurements, ${ }^{11}$ whereas LOBO \& GOEBELSMAN used a standardized DHEA-S measurement as a criterion. ${ }^{12}$ Other authors have emphasized the DHEA/androstenedione ratio, ${ }^{5}$ whereas REDMOND et al. prefer the use of urinary metabolites. ${ }^{13}$

The tretacosatide depot (ACTH-depot) forms a complex with zinc hydroxide when used in the intramuscular form, with a slow and chronic ACTH release for a period of no less than 36 to 48 hours. Clinically, it is used in situations in which it is desirable to increase serum cortisol levels. Like intravenous ACTH, it can also be used to diagnose adrenal synthesis deficiencies due to the more potent and prolonged stimulus it provides for the three adrenal layers, chronically depleting their production.

PRATA LIMA, in a study of the effect of ACTH on normal women and women with idiopathic hirsutism, suggested criteria for the diagnosis of 3-HSD deficiency after detecting a considerable increase in the hormones of the fasciculated layer and a significant elevation of peripheral androgens such as S-DHEA and testosterone, a fact that is not observed when intravenous ACTH is used. ${ }^{14}$

\section{CONCLUSIONS}

Today, some reports tend to disregard the ACTH test. There are two reasons behind this attitude. The first has to do with the fact that 21-OH deficiency, by being linked to the HLA system, would not require the test but simply an analysis of these histocompatibility antigens. However, the cost of, and difficult access to this procedure are not taken into consideration. BARNES et al. stated that the excessive number of patients with 3-HSD deficiency reported over the last few years should be considered with some caution since there may be other changes in steroid metabolism that simulate this defect. ${ }^{15}$ However, the fact that an HLAlinked antigen for the deficiency has not yet been identified cannot rule out the test.

Thus, the test using ACTH stimulation by the conventional method or use of the ACTH-depot may be of help in the reproductive and endocrine function of women in general with menstrual and aesthetic repercussions. 


\section{RESUMO}

O teste com ACTH tem sido utilizado para diagnosticar patologias como a insuficiência supra-renal, e as formas clássica e não-clássica de hiperplasia supra-renal em decorrência de deficiências enzimáticas. Revisou-se vários aspectos históricos envolvendo o uso do ACTH no diagnóstico do hirsutismo e são analisadas suas principais indicaçōes. Apesar dos novos avanços em biologia molecular no diagnóstico das deficiências enzimáticas das supra-renais, o uso do teste com ACTH pode ajudar o clínico a predizer o genótipo e fenótipo dos individuos que apresentam manifestaçōes hiperandrogênicas devido à hiperplasia congênita da supra-renal na sua forma nāo-clássica.

\section{REFERENCES}

1. Thorn GW, Forsham PH, Prunty FG. A test for adrenocortical insufficiency: The response to pituitary adrenocorticotropic hormone. JAMA 1948;137:1005-9.

2. Jenkins D, Forsham PH, Laidlaw JE. Use of ACTH in the diagnosis of adrenal insufficiency. Am J Med 1955;18:3-14.

3. Pang S, Lenore LS, Stoner E. Nonsalt-losing congenital adrenal hyperplasia due to 3 -Hydroxysteroid dehydrogenase deficiency with normal glomerulosa function. J Clin Endocrinol Metab 1983;56:808-18.

4. Yamaji T, Ibayashi H. Plasma dehydroepiandrosterone sulfate in normal and pathological conditions. J Clin Endocr 1969;29:273-78.

5. Griffting GT, Allen J, Pratt H, Melby JC. Discordance of plasma DHEA-S, DHEA, and cortisol responses with various ACTH regimens. Metabolism 1985;34:631-36.

6. Eldar-Geva T, Hurwitz A, Vecsei P, Milwidsky A, Rosler A. Secondary biosynthetic defects in women with late-onset congenital adrenal hyperplasia. N Engl J Med 1990;323:85563.

7. Chetkowiski RJ, Defazio J, Shamonki I, Judd HL, Chang J. The incidence of late-onset congenital adrenal hyperplasia due to 21-hydroxylasedeficiency among hirsute women. J Clin Endocr Metab 1984;58:595-98.

8. Azziz R, Zacur HA. 21-hidroxylase deficiency in female hyperandrogenism: Screening and diagnosis. J Clin Endocrinol Metab 1989;69:577-84.
9. Dewailly D, Vantyghem-Haudiquet Mc, Sainsard C. Clinical and biological phenotypes in late-onset 21-hidroxylase deficiency. J Clin Endocrinol Metab 1986;63:418-23.

10. Pang S, Lerner AJ, Storner E. Late onset adrenal steroid 3hydroxysteroid dehydrogenase deficiency. A cause of hirsutism in punertal and non-pubertal women. J Clin Endocrinol Metab 1985;60:428-39.

11. Gibson M, Lackritz R, Schiff I, Tulchinsky D. Abnormal adrenal responses to adrenocorticotropic hormone in hyperandrogenic women. Fertil Steril 1980;33:43-49.

12. Lobo RA, Goebelsmann U. Evidence for reduced 3-olhydroysteroid desidrogenase activity in some women thought to have polycystic ovary syndrome. J Clin Endocrinol Metab 1981:53:394-400.

13. Redmond G.P, Bedocs N, Skibinski C. Attenuated adrenal hyperplasia and other abnormalities of steroid metabolism in women with androgen disorders. Prog Abst, 70th Annual Meeting of Endocrine Society, June, 1988:740-45.

14. Prata Lima MF. Avaliação da atividade da 3-hidroxiesteróide desidrogenase em mulheres hirsutas após estímulo com ACTH-depot. Tese mestrado- Escola Paulista de Medicina 1994.

15. Barnes RB, Ehrmann DA, Brigell DF, Rosenfield RL. Ovarian steroidogenic responses to gonadotropin-releasing hormone agonist testing with nafarelin in hirsute women with adrenal responses to adrenocorticotropin hormone suggestive of 3-hydroxy-5-steroid dehydrogenase deficiency. J Clin Endocrinol Metab 1993;76:450-55. 